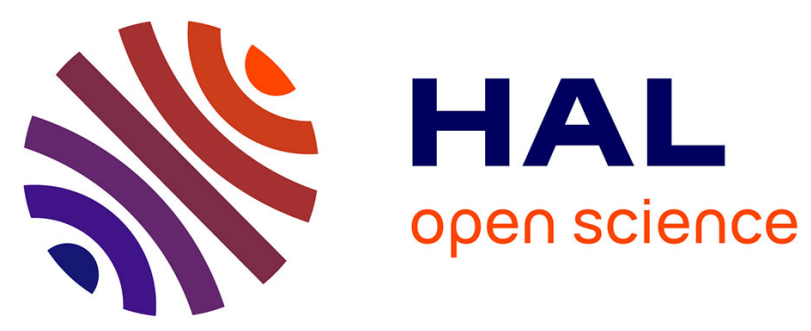

\title{
Labrador current variability over the last 2000 years
}

Marie-Alexandrine Sicre, Kaarina Weckström, Marit-Solveig A. Seidenkrantz, Antoon Kuijpers, Marion Benetti, Guillaume Massé, Ullah Ezat, Sabine Schmidt, Ioanna Bouloubassi, Jesper Olsen, et al.

\section{- To cite this version:}

Marie-Alexandrine Sicre, Kaarina Weckström, Marit-Solveig A. Seidenkrantz, Antoon Kuijpers, Marion Benetti, et al.. Labrador current variability over the last 2000 years. Earth and Planetary Science Letters, 2014, 400, pp.26-32. 10.1016/J.EPSL.2014.05.016 . hal-01060154

\section{HAL Id: hal-01060154 https://hal.science/hal-01060154}

Submitted on 15 Jan 2022

HAL is a multi-disciplinary open access archive for the deposit and dissemination of scientific research documents, whether they are published or not. The documents may come from teaching and research institutions in France or abroad, or from public or private research centers.
L'archive ouverte pluridisciplinaire $\mathbf{H A L}$, est destinée au dépôt et à la diffusion de documents scientifiques de niveau recherche, publiés ou non, émanant des établissements d'enseignement et de recherche français ou étrangers, des laboratoires publics ou privés. 


\section{$1 \quad$ Labrador Current variability over the last 2000 years}

2

3 M.-A. Sicre ${ }^{1,2}$, K. Weckström ${ }^{3}$, M.-S. Seidenkrantz ${ }^{4}$, A. Kuijpers ${ }^{3}$, M. Benetti ${ }^{2}$, G. Masse ${ }^{5}$, U. Ezat ${ }^{2}$,

${ }^{1}$ Laboratoire d'Océanographie et du Climat: Expérimentation et Approches Numériques (LOCEAN), IPSL-UPMC/CNRS/IRD/MNHN, Paris, France (present address). Tel : + 33144278414 ; Fax : 33 1442749 93; e-mail : sicre@Isce.ipsl.fr

${ }^{2}$ Laboratoire des Sciences du Climat et de I'Environnement, IPSL/CNRS/CEA, Gif-sur-Yvette Cedex, France.

${ }^{3}$ Geological Survey of Denmark and Greenland, Department of Marine Geology and Glaciology, Copenhagen, Denmark.

${ }^{4}$ Centre for Past Climate Studies and Arctic Research Centre, Department of Geoscience, Aarhus University, Denmark.

${ }^{5}$ Takuvik, UMI 3376, 1045 Avenue de la Médecine, G1V 0A6 Québec, QC, Canada

${ }^{6}$ CNRS EPOC, UMR 5805, F-33400, Université Bordeaux-1, Talence, France.

${ }^{7}$ The Aarhus AMS ${ }^{14} \mathrm{C}$ Dating Centre, Department of Physics and Astronomy, Aarhus University, Denmark.

${ }^{8}$ Climate and Environmental Physics, Physics Institute, University of Bern, Switzerland.

\section{Abstract}

The ice-loaded Labrador Current (LC) is an important component of the western North Atlantic circulation that influences the position and strength of the northern limb of the North Atlantic Current (NAC). This flow of cold and fresh Polar Waters originating from the Arctic has a marked impact on the North Atlantic climate, yet little is known about its variability beyond the instrumental period. In this study, we present the first sub-decadal alkenone-based 2000-year long sea-surface temperature (SST) records from the western Labrador Sea, a climatically crucial region at the boundary between the LC and the NAC. Our results show a clear link between the LC strength and the Northern Annular Mode (NAM), with a stronger NAM and a more vigorous LC during the Medieval Climate Anomaly (MCA). This suggests enhanced LC activity upon future global warming with implications for the Atlantic meridional overturning circulation (AMOC). 
Keywords: ocean variability, temperature proxy, last millennia, Labrador Sea, Newfoundland, Northern Annular Mode

\section{Introduction}

Climate in the North Atlantic region is strongly influenced by Arctic Ocean waters exported to the mid-latitudes of the North Atlantic Ocean through Fram Strait (Eastern Route) and the Canadian Archipelago/western Labrador Sea (Western Route) (Fig. 1). These low-density waters affect deep convection in the Labrador and Greenland Seas and, subsequently, the strength of the global thermohaline circulation and climate (Jones and Anderson, 2008). The LC accounts for about two thirds of the freshwater outflow from the Arctic Ocean (Aksenov et al., 2010). A sharp front separates the fresh and cold shelf waters of this boundary current from the warmer and saltier open-ocean waters of the Labrador Sea. Before reaching Hamilton Bank (ca. $54^{\circ} \mathrm{N}$ ) offshore Labrador, the LC splits into a major outer branch trapped at the edge of the continental slope, and a minor inner branch ( $15 \%$ of the total transport) flowing over the Newfoundland shelf (Lazier and Wright, 1993). Along its path, the LC has little exchange with the central Labrador Sea. In the region of Flemish Cape and the Grand Banks east of Newfoundland, the LC retroflects northwards when encountering the NAC (Fratantoni and McCartney, 2010). The resulting freshening and cooling of the NAC on its way to the Nordic Seas are crucial processes controlling the rate and intensity of the AMOC, thus impacting European climate (Czaja and Frankignoul, 2002).

Today, the LC variability and the position of the northern edge of the NAC are strongly influenced by the Northern Annular mode (NAM) (Dickson et al., 1996), which is defined from sea level atmospheric pressure between 20 and $90^{\circ} \mathrm{N}$ and reflects the degree of penetration of Arctic air into mid-latitudes. Deep Icelandic lows during ${ }^{+}$NAM years favour NW winds bringing cold air from the Arctic over the Labrador Sea, which results in colder-than-normal winter SSTs, sea-ice formation and enhanced transport of ice-loaded LC waters (Drinkwater, 1996). In contrast, weaker Westerlies and more frequent southerly winds during -NAM years reduce winter ocean heat loss and promote warmer SSTs. NAM also induces changes in the Arctic Water gateways with implications for the deep convection. Under -NAM conditions, the Transpolar Drift of Polar Waters shifts eastwards towards Fram Strait (Morison et al., 2012). The East Greenland Current (EGC)/ West Greenland

61 Current (WGC) system is subsequently enhanced, which intensifies buoyancy-driven transport 62 (Dickson et al., 1996) and leads to a more southerly NAC, as seen during the persistent and 
extreme -NAM phase in the late 1960s (the 'Great Salinity Anomaly' (GSA)) (Dickson et al., 1988). Buoyancy gain combined with diminished ocean heat loss reduces deep convection in the central Labrador Sea and thus weakens the subpolar gyre (SPG) circulation (Dickson et al., 1996). In contrast, under ${ }^{+}$NAM conditions, Arctic Waters are routed through the Canadian Archipelago and the LC transport increases under the influence of stronger NW winds (Fratantoni and McCartney, 2010). Concurrently, increased ocean heat loss favors enhanced convection in the central Labrador Sea, thus reinforcing SPG circulation and mixing with subtropical waters through the intergyre circulation (Marshall et al., 2001).

In recent years, efforts have been made to produce high-resolution SST reconstructions of the last millennia (PAGES 2k Consortium, 2013; Cunningham et al., 2013). However, despite its significance for the AMOC, the Labrador Sea region has hitherto remained poorly documented at decadal time scales over the past thousand years. Here, we present two sub-decadal alkenonederived SST records from northeastern and southeastern Newfoundland coastal waters covering the last 2000 years. The NE site was selected to be representative of LC waters, while the SE site is located in the boundary zone between the LC and the Gulf Stream. The alkenone records thus allow us not only to track changes in SSTs but also to evaluate variations of the LC/Gulf Stream boundary.

\section{Material and Methods}

\subsection{Sediment sampling.}

A set of one box-core and one gravity core were collected at each study site during the research cruise on the Russian RV Akademik Ioffe, September 23-28, 2007. Box-core AI07-04BC (39.5 cm) and gravity core AI07-03G $(460 \mathrm{~cm})$ were retrieved from Bonavista Bay $\left(48^{\circ} 44 \mathrm{~N}, 53^{\circ} 29 \mathrm{~W} ; 329 \mathrm{~m}\right.$ depth), offshore northeastern Newfoundland (Fig. 1). Box-core AI07-11BC (47¹4N; 5436W, 233 $\mathrm{m}$ water depth, $(41 \mathrm{~cm})$ and gravity core AI07-12G (47008N; 5433W; 230 water depth, $459 \mathrm{~cm})$ were collected in Placentia Bay, off southeastern Newfoundland. The cores were taken from small sedimentary basins identified by a Parasound sub-bottom profiler and show no evidence of sediment re-working. Strong currents prevail over the shelf, but local sedimentary basins in fjords and open bays in direct connection to the open ocean offer suitable sedimentary conditions. The box-cores were analyzed every $0.5 \mathrm{~cm}$ over the first $2 \mathrm{~cm}$, and then every $1 \mathrm{~cm}$. The gravity cores were analyzed every $0.5 \mathrm{~cm}$. 


\subsection{Sediment dating.}

96 Dating of the box-cores (AI07-04BC and AI07-11BC) was performed from excess activity of ${ }^{210} \mathrm{~Pb}$ $97 \quad\left({ }^{210} \mathrm{~Pb}_{\mathrm{xs}}\right)$ (Fig. 2) (Weckström et al., 2013). ${ }^{210} \mathrm{~Pb},{ }^{226} \mathrm{Ra}$ and ${ }^{137} \mathrm{Cs}$ activities were analysed using a 98 low background, high efficiency, well-shaped $\gamma$ detector (Schmidt et al., 2009), calibrated with certified reference material (IAEA-RGU-1). Activities are expressed in $\mathrm{mBq} \mathrm{g}^{-1}$ and errors are based on $1 \mathrm{SD}$ counting statistics. Excess ${ }^{210} \mathrm{~Pb}$ was calculated by subtracting the activity supported by its parent isotope, ${ }^{226} \mathrm{Ra}$, from the total ${ }^{210} \mathrm{~Pb}$ activity in the sediment. Errors in ${ }^{210} \mathrm{~Pb}_{\mathrm{xs}}$ were calculated by propagation of errors in the corresponding pair $\left({ }^{210} \mathrm{~Pb}\right.$ and $\left.{ }^{226} \mathrm{Ra}\right)$. The sedimentation rate was calculated from ${ }^{210} \mathrm{~Pb}_{\mathrm{xs}}$ profiles using a constant flux-constant sedimentation (CF:CS) model. The

$104 \mathrm{SE}$ Newfoundland core displays a two-layer ${ }^{210} \mathrm{~Pb}_{\mathrm{xs}}$ profile, which was taken into account when calculating the sedimentation rate. Age models were calculated assuming an age of 2007 at the core-tops. No clear signs of disturbance caused by bioturbation are observed in the surface sediments. Furthermore, the lithology of the gravity cores indicates fine laminations throughout the sediment sequence, which provides evidence for the sedimentary record being undisturbed by biological reworking.

110 The age models for the gravity cores (AI07-03G and AI07-12G) were established using the 111 depositional model option in the OxCal 4.1 software using marine ${ }^{14} \mathrm{C}$ calibration curve Marine09 112 with an average $\Delta \mathrm{R}$ of $139 \pm 61$ years (Solignac et al., 2011; Jessen et al., 2011; Reimer et al., 113 2009)(Table 1). Core AI07-03G spans the last 5740 years (age of core-top $170 \pm 90 \mathrm{cal}$ yr BP 114 according to the age model), with sedimentation rates ranging from 36 to $143 \mathrm{~cm} / \mathrm{kyr}$. Only the 115 age model for the last 2000 years is shown here (Fig. 3). The age model is based on 7 AMS ${ }^{14} \mathrm{C}$ 116 dated samples of mixed benthic foraminifera or shell fragments ( 1 outlier) and was constructed 117 with a k-value of 150 yielding an agreement index of $A_{\text {model }}$ of $110 \%$. AI07-12G covers the last 1186000 years, with the core-top at $176 \pm 102$ cal. yr BP, and sedimentation rates ranging from 69 and $11998 \mathrm{~cm} / \mathrm{kyr}$. The age model of the last 2000 years (Fig. 3) is based on 6 AMS ${ }^{14} \mathrm{C}$ dated mixed 120 benthic foraminifera and shell fragments ( 2 outliers) and was constructed with a k-value of 50 121 yielding an agreement index of $A_{\text {model }}$ of $84 \%$. Age model uncertainties range from $\sim 70-110$ years 122 (core AI07-03G) and 70-115 years (core AI07-12G). 
Alkenones were extracted from freeze-dried sediments (methanol/methylene chloride; $1: 2 \mathrm{v} / \mathrm{v}$ ), purified by open column silica gel chromatography and then analyzed by gas chromatography on a Varian CX3400 equipped with a CP-Sil-5 capillary column (50 m x $0.32 \mathrm{~mm}$ i.d.) and a flame

128 ionization detector (Ternois et al., 1996). SSTs were calculated from the $\mathrm{U}^{\mathrm{K}^{\prime}, 37}$ index $\mathrm{C}_{37: 2} /\left(\mathrm{C}_{37: 2}+\right.$ $\left.129 \mathrm{C}_{37: 3}\right)$ using the calibration of Prahl et al.(1988) (SST $=\left(\mathrm{U}^{\mathrm{K}^{\prime}, 37}\right.$-0.039)/0.034). Internal precision 130 for SST estimates is less than $0.5^{\circ} \mathrm{C}$ (Ternois et al., 1996).

\section{Results and discussion}

\subsection{Alkenone-SST signal over the recent decades}

134 SSTs for the recent decades were obtained from the two box-cores (AI07-04BC; AI07-11BC) 135 (locations shown in Fig. 1) and compared to the NAM index (Fig. 4a). The NE Newfoundland record 136 covers 80 yrs (AI07-04BC; 1925-2007 AD) while the SE Newfoundland one spans 125 yrs (AI07$13711 \mathrm{BC} ; 1880-2007 \mathrm{AD}$ ), the former allowing a higher temporal resolution (2.5 yrs) than the latter 138 (4.1 yrs) (Fig. 4b,c). SSTs vary between 4.5 and $5.5^{\circ} \mathrm{C}$ off NE Newfoundland, and between 3.5 and $1394.5^{\circ} \mathrm{C}$, off SE Newfoundland. This is at odds with the generally warmer instrumental SSTs in SE 140 Newfoundland (Fig. 5), suggesting differences in the alkenone production patterns between the two 141 sites.

142 Today, the NE Newfoundland site is mainly influenced by the LC and sea-ice covered for 2-3 143 months per year ( 11 month)

144 (http://nsidc.org/data/docs/noaa/g00799_arctic_southern_sea_ice/index.html). SSTs range from $1450.5^{\circ} \mathrm{C}$ in winter to $\sim 11^{\circ} \mathrm{C}$ in summer (annual mean $4.2^{\circ} \mathrm{C}$ ) (Fig. 5). Off SE Newfoundland SSTs are 146 slightly higher, spanning from $0.9^{\circ} \mathrm{C}$ in winter to $12.5^{\circ} \mathrm{C}$ in summer (annual mean $5.4^{\circ} \mathrm{C}$ ) (Fig. 5).

147 This site, located at the southern edge of the LC where it borders towards the NAC, is generally 148 ice-free during winter. Owing to the pronounced hydrographical gradients in the Newfoundland 149 region, distinct biological seasonal patterns occur over rather short distances (Nezlin et al., 2002). 150 Off NE Newfoundland, where the influence of the LC is stronger, primary production follows a 151 typical Arctic regime with a slow increase from January to June, followed by a decrease towards 152 stable values from August to December. Off SE Newfoundland, less impacted by the LC, 153 phytoplankton blooms in spring and fall, as generally observed at mid-latitudes. These differences 154 are primarily ascribed to the water column structure affecting light and nutrient conditions in the 155 upper layer (Nezlin et al., 2002). Under strong turbulent mixing conditions such as those in LC 
156 waters (NE Newfoundland), nutrients are available, but cells tend to disperse into deeper layers

157 where light becomes limiting for phytoplankton growth. As the water column stabilizes, primary 158 production progressively increases and reaches its highest level relatively late (spring/summer). In

159 contrast, generally weaker mixing in the less turbulent waters off SE Newfoundland allows for a 160 phytoplankton bloom already in early spring, resulting in alkenone production at cooler 161 temperatures than off NE Newfoundland. In addition, along NE Newfoundland sea ice generally 162 persists until early May, while waters offshore SE Newfoundland are usually ice-free all year. An 163 earlier phytoplankton blooming in ice-free waters off SE Newfoundland would result in colder 164 alkenone (early spring) SSTs compared to NE Newfoundland where alkenone production would not 165 take place until sea ice has melted (late spring-summer). A positive temperature offset was 166 previously reported off North Iceland (Sicre et al., 2011), close to the polar front where, during 167 heavy ice years, alkenone-SSTs appear systematically biased towards warmer months when 168 compared to instrumental data, suggesting that sea ice retarded the spring bloom. We can thus 169 conclude that both turbulent conditions and sea ice occurrence likely contribute to a shift towards 170 warmer values of the alkenone-derived SSTs in NE Newfoundland. Higher values by $\sim 1^{\circ} \mathrm{C}$ off NE 171 Newfoundland $\left(4.5-5.5^{\circ} \mathrm{C}\right)$ as compared to SE Newfoundland $\left(3.5-4.5^{\circ} \mathrm{C}\right)$ would thus reflect 172 delayed blooming (Nezlin et al., 2002) due to the presence of sea ice (Sicre et al., 2011).

173 Figure 4 shows the time-series (Fig. 4b,c) at both sites and the NAM index (Fig. 4a). Proxy records 174 NE and SE of Newfoundland exhibit decadal-scale variability superimposed on a general cooling 175 trend and show differences over the common time window (1930-2007). Correlations were 176 calculated between SSTs and NAM index values for the two cores (AI07-04BC and AI07-11BC). The 177 number of degrees of freedom between the two time series was computed following Bretherton et 178 al. (1999), taking into account the autocorrelation of each time series. Because alkenone-derived 179 SSTs represent an average value over the sediment sampling step (1 cm and $0.5 \mathrm{~cm}$ for the top 180 two cms), correlations were calculated between SSTs and the NAM index value averaged over the 181 time interval of each sediment layer, i.e. corresponding to $1 \mathrm{~cm}$ in most of the core and $0.5 \mathrm{~cm}$ at 182 the top. We found that the NE Newfoundland SSTs are negatively correlated with the NAM index 183 average over the same time interval as the SSTs $(r=-0.63$, with $p<0.05$ according to a 2 -sided 184 Student test and with 23 degrees of freedom). The statistical significance of this correlation is 185 confirmed by a bootstrap approach with 1000 permutations. In particular, lowest SST values are 186 reached during the late 1980s and early 1990s of high +NAM (Drinkwater, 1996; Morison et al., 187 2012), as expected from strong NW winds. Increased sea ice has previously been described for the 
same period (Weckström et al., 2013). Conversely, correlation between NAM and SSTs off SE

189 Newfoundland is not significantly different from 0 at the $95 \%$ confidence level $(r=0.07)$. Local

190 atmospheric and hydrographical conditions most likely explain the different SSTs/NAM relationship.

191 While the NE Newfoundland site is located in the subpolar zone which strongly responds to NAM

192 today (Thompson and Wallace, 1998), the SE Newfoundland site is transitional in-between subpolar

193 and subtropical climate influences and also reflects the (sub)tropical ocean signal propagated by

194 the NAC. Correlations between proxy SSTs and the NAM index at both sites are fully consistent

195 with the modern SST/NAO correlation map for in the North Atlantic region (Marshall et al., 2001)

196 and subsequently reinforce our interpretation of the two proxy records. Even more importantly, the

197 remarkable agreement with Marshall et al. (2001) emphasizes that our SST records are of large-

198 scale significance.

199

\subsection{SST variability over the last two millennia}

201 SSTs of the last $\sim 2000-y r$ from NE and SE Newfoundland were reconstructed from two gravity 202 cores (AI07-03G; AI07-12G) and compared with SSTs from N. Iceland (Figs. 1 and 6). Due to 203 minor losses of surficial sediments during the coring operation, the core-top ages are estimated to 204 be 1775 AD for AI07-03G and 1770 AD for AI07-12G. Off NE Newfoundland, SSTs range between 2054.5 and $6^{\circ} \mathrm{C}$ and show decadal-scale variability with a colder interval at 1000-1350 AD, 206 approximately concurrent with the Medieval Climate Anomaly (MCA) (Fig. 6b). Both the well207 defined onset and termination of this interval occurred within only a few decades. During the Little 208 Ice Age (LIA), SSTs are generally warmer than during the MCA, showing marked warm spells at $209 \sim 1470-1480 \mathrm{AD}$ and cold ones at $\sim 1440-1460$ AD and $\sim 1710-1750$ AD. In contrast, SSTs off SE 210 Newfoundland rapidly decrease until $\sim 1000 \mathrm{AD}$ and thereafter fluctuate around $\sim 4^{\circ} \mathrm{C}$ (Fig. $6 \mathrm{C}$ ). The 211 absence of contrasting MCA/LIA conditions here is notable and consistent with dinocyst data from 212 the same core (Solignac et al., 2011) as well as with alkenone data off Nova Scotia (Keigwin et al.,, 213 2003). At the NE site, dinocyst variability was even smaller, being primarily affected by freshwater 214 supply and productivity during this time interval (Solignac et al., 2011).

215 The two sites thus clearly show different oceanographic patterns during the last 2000 years. The 216 SE site mainly illustrates the general late Holocene cooling trend of the North Atlantic region with 217 little or no clear difference between the MCA and LIA. In contrast, the NE Newfoundland site shows 218 strong multi-centennial SST variability and colder SSTs during the MCA. This surface-water cooling 
can be compared to the present-day ocean response to strong NW winds during ${ }^{+}$NAM years 220 (Drinkwater, 1996; Morison et al., 2012) (Fig. 4). Likewise, warmer SSTs before 1000 AD and after $2211350 \mathrm{AD}$ (LIA) can be linked to LC weakening as a result of reduced NW winds combined with more 222 frequent southerly winds during -NAM years (Morison et al., 2012). Note that the MCA cooling in NE 223 Newfoundland corresponds to a warming of a similar magnitude $\left(\sim 1^{\circ} \mathrm{C}\right)$ observed in North Iceland 224 shelf waters (Figs. 1,6a; MD99-2275), which has been attributed to ${ }^{+}$NAM-type atmospheric 225 circulation and an enhanced AMOC (Sicre et al., 2011; Trouet et al., 2009). Previous low-resolution 226 SST reports from the NW Atlantic also hypothesized +NAO-like conditions during the MCA (Keigwin, 1996; Seidenkrantz et al., 2007; Seidenkrantz et al., 2008). Furthermore, higher proportions of 228 subpolar waters at intermediate depths evidenced at the Rockall Trough (Copard et al., 2012) are 229 in agreement with stronger Westerlies and intensified SPG circulation in a ${ }^{+}$NAM scenario. This 230 coherent regional pattern of proxy records is overall consistent with the Trouet et al. (2009) and 231 Olsen et al. (2012) long-term reconstructions of the NAO index and the suggestion of a persistent 232 positive phase during the MCA (Seidenkrantz et al., 2007; Seidenkrantz et al., 2008; Trouet et al., 233 2009, 2012; Ribeiro et al., 2012; Andresen et al., 2013). Although this mode of variability operates 234 mainly at interannual time scales, the SST/NAO correlation tripole shows a pronounced signature at 235 decadal time scales as well (Marshall et al., 2001) suggesting the role of NAM on climate at lower 236 frequency (Boessenkool et al. 2007).

237 Enhanced AMOC and northward heat transport during the MCA could also have triggered coastal 238 glacier melting, subsequently increasing the discharge of cold/melt waters into Greenland coastal 239 waters, while further offshore, the warm Irminger Sea Water signal was still present. This pattern 240 has been documented in several studies showing surface-water cooling and/or increased sea-ice 241 during the MCA in coastal W/SW-Greenland sites (Jensen et al., 2004; Seidenkrantz et al., 2007; 242 Seidenkrantz et al., 2008; Andresen et al., 2011), while elevated SSTs were observed further 243 offshore between 1000-1350 AD (Ribeiro et al., 2012) and 800-1330 AD (Sha et al, 2012).

244 Therefore, apart from the SST response to direct wind forcing, colder LC waters during the MCA 245 may also in part reflect advection of freshwater and ice by the WGC (Morison et al., 2012), since 246 south of David Strait the majority of this flow turns westwards and reaches the continental slope of 247 W-Labrador (Fig. 1) (Schmidt et al., 2007). Moreover, as outlined before (see Fratantoni and 248 McCartney, 2010), a re-routing of Arctic waters through the Canadian Archipelago may be another 249 important factor explaining negative SST anomalies of the LC during Medieval times. 
During the LIA, warmer SSTs found along NE Newfoundland coincide with colder and heavy ice 251 years off North Iceland (Massé et al., 2008). This pattern compares well with surface ocean 252 conditions during NAM years, the GSA being an extreme example. Large quantities of freshwater 253 and ice exported through Fram Strait (Dickson et al., 1996) contribute to the reduction of Labrador 254 Sea convection. Thus, NAM not only affects local climate through wind forcing but also exerts control on the convective activity of the Labrador region by activating either the Fram Strait Route 256 ('NAM) or the Canadian Archipelago Route ( $\left.{ }^{+} \mathrm{NAM}\right)$, with different consequences for the AMOC.

\section{Conclusions}

Our two distinct SST records, one within the LC (NE Newfoundland) and the other at the northern edge of the NAC (SE Newfoundland), provide new insight into the overall interaction between the LC and the NAC. The SE Newfoundland SST record reveals an overall weaker influence of the NAC through the last 2000 years with only little variability at (multi)centennial scale. In contrast, the NE Newfoundland record shows that LC circulation is tightly linked to Arctic atmospheric conditions (NAM), which in turn modulate the advection pathway of cold, ice-loaded Polar Waters from the Arctic. This is illustrated by virtue of a generally enhanced LC during the MCA, and an overall weaker LC and likely decreased AMOC during the LIA (Lund et al., 2006). If this MCA/LIA pattern is to be considered analogous to generally warmer/colder climates in the subpolar North Atlantic, it would suggest the possibility of increasing LC strength in a future warmer climate. This would not only imply a colder future climate off eastern Canada, but would also affect regional oceanatmosphere interaction off Newfoundland, deep convection in the Labrador Sea, NAC heat transport, and thus, climate in the larger North Atlantic realm.

Acknowledgements. The research presented here was supported by the French LEFE/INSU NAIV project (CNRS/INSU) and the ERC 203441 starting grant ICEPROXY project. K.W. was funded via a

275 Marie Curie IEF grant (agreement no. 236678). MSS and AK received funding via the TROPOLINK 276 and OCEANHEAT projects supported by the Danish Council for Independent Research Natural 277 Science (FNU Grants 09-069833 and 12-126709). The cruise was funded by the Danish Council for 278 Independent Research, Natural Science (project no. 272-06-0604/FNU) and carried out within the 279 Danish-Russian collaboration project 'Joint paleoceanographic investigations in the Labrador Sea 280 region'. This work is a contribution to the EU FP7 project 'Past4Future' (project no. 243908). 


\section{References}

282 Aksenov, Y., Bacon, S., Coward, A. C., Holliday, N. P., 2010. Polar outflow from the Arctic Ocean: A high-resolution model study. J. Marine Syst. 83, 14-37.

284 285

Andresen, C. S., McCarthy, D. J., M., Dylmer, C. V., Seidenkrantz, M.-S., Kuijpers, A. Lloyd, J., 2011. Interaction between subsurface ocean waters and calving of Jakobshavn Isbræ during the late Holocene. The Holocene 21, 211-224.

Andresen, C.S., Hansen, M.J., Seidenkrantz, M.-S., Jennings, A.E., Knudsen, M.F., NørgaardPedersen, N., Larsen, N.K., Kuijpers, A., Pearce, C., 2013. Mid- to late-Holocene oceanographic variability on the Southeast Greenland shelf. The Holocene 23 (2), 167-178; doi: $10.1177 / 0959683612460789$

Boessenkool, K.P., Hall, I.R., Elderfield, H., Yashayaev, I., 2007. North Atlantic climate and deepocean flow speed changes during the last 230 years. Geophys. Res. Lett. 34, L13614 doi: 10.1029/2007GL030285.

Bretherton, C.S., Widmann, M. Dymnikov, V.P., Wallace, J.M., Blade, I. (1999). Effective number of degrees of freedom of s spatial field. J. Clim. 12, 1990-2009.

Czaja, A., Frankignoul, C., 2002. Observed impact of Atlantic SST anomalies on the North Atlantic Oscillation. J. Climate 15, 606-623.

Fratantoni, P. S., McCartney, M. S., 2010. Freshwater export from the Labrador Current of the north Atlantic Current at the Tail of the Grand Banks of Newfoundland. Deep-Sea Res.I 57, 258283.

Copard, K., Colin, C., Henderson, G.M., Scholten, J., Douville, E., Sicre, M.-A., Frank, N., 2012. Late Holocene intermediate water variability in the Northeastern Atlantic as recorded by deep-sea corals, Earth Planet. Sci. Lett. 313-314, 34-44.

Cunningham, L.K., Austin, W.E.N., Knudson, K-L., Eiriksson, J., Scourse, J., Wanamaker Jnr, A., Butler, P., Cage, A., Kristensen, D.K., Richter, T., Husum, K., Hald, M., Andersson, C. , Zorita, E., Linderholm, H., Gunnarson, B., Sicre, M.-A., Sejrup, H.P., Jiang, H., and Wilson, R.J.S., Reconstructions of surface ocean conditions from the North East Atlantic and Nordic Seas during the last millennium, The Holocene, 23, 7, 921-935, 2013. 
Dickson, R. R., Meincke, J., Malgrem, S.-A., Lee, J.A., 1988. The great salinity anomaly in the

310 Northern north Atlantic 1968-1982. Progr. Oceanogr. 20, 103-151.

311 Dickson, R. R., Lazier, J., Meincke, J., Rhines P., Swift, J., 1996. Long-term coordinated change in 312 the convective activity of the north Atlantic. Progr. Oceanogr. 38, 241-295.

313 Drinkwater, K. F., 1996. Climate and oceanographic variability in the Northwest Atlantic during the 314 1980s and early-1990s. J. Northw. Atl. Fish. Sci. 18, 77-97.

Jensen, K. G., Kuijpers, A., Koç, N., Heinemeier, J., 2004. Diatom evidence of hydrographic

316 changes and ice conditions in Igaliku Fjord, South Greenland, during the past 1500 years. The 317 Holocene 14, 152-64.

Jessen, C.A., Solignac, S., Nørgaard-Pedersen, N., Mikkelsen, N., Kuijpers, A., Seidenkrantz, M.-S., 319 2011. Exotic pollen as an indicator of variable atmospheric circulation over the Labrador Sea region during the mid to late Holocene. Journal of Quaternary Science 26(3), 286-296; doi:

Jones, E. P., Anderson, L.G., 2008. Is the global conveyor belt threatened by Arctic Ocean fresh water outflow? In: Dickson RR, Meincke J., Rhines, P. Eds. Arctic-Subarctic Ocean fluxes.

Keigwin, L. D., 1996. The little Ice Age and Medieval Warm Period in the Sargasso Sea. Science $274,1504-1508$.

Keigwin, L., Sachs, J.P., Rosenthal Y., 2003. A 1600-year history of the Labrador Current off Nova Scotia. Clim. Dyn. 21, 53-62.

Lazier, J. R. N., Wright, D. G., 1993. Annual velocity variations in the Labrador Current. J. Phys. Oceanogr. 23, 659-678.

Lund, D. C., Lynch-Stieglitz, J. Curry, W. B., 2006. Gulf Stream density structure and transport during the past millennium. Nature 444, 601-604.

334 R., Visbeck M., 2001. North Atlantic Climate variability: phenomena, impacts and mechanisms. Int. J. Climatol. 21, 1863-1898.

336 Massé, G., Rowland, S., Sicre, M.-A., Jacob, J., Jansen, E., Belt, S., 2008. Abrupt climate changes 337 for Iceland during the last millennium. Evidence from high resolution sea ice reconstructions. 
Morison, J., Kwok, R., Peralta-Feriz, C., Alkire, M., Rigor, I., Andersen, R., Steele, M., 2012.

Nezlin, N.P., Afanasyev, D., Ginzburg, A.I., Kostianoy, A.G., 2002. Remotely sensed studies of phytoplankton dynamics under physical forcing in different ocean regions. Ad. Space res. 29, 99106.

Olsen, J., Anderson, J.N., Knudsen, M.F., 2012. Variability of the North Atlantic Oscillation over the past 5,200 years. Nature Geoscience 5, 808-812, doi:10.1038/ngeo1589.

Prahl, F.G., Muehlhausen, L.A., Zahnle, D.L., 1988. Further evaluation of long-chain alkenones as indicators of paleoceanographic conditions. Geochim. Cosmochim. Acta 52, 2303-2310.

PAGES 2k Consortium, 2013. Continental-scale temperature variability during the past two millennia. Nature Geoscience 6, 339-346; doi:10.1038/ngeo1797.

Reimer, P. J., M. G. L. Baillie, E. Bard, A. Bayliss, J. W. Beck, P. G. Blackwell, C. B. Ramsey, C. E.

Ribeiro, S., Moros, M., Ellegaard, M., Kuijpers, A., 2012. Climate variability in West Greenland through the past 1500 years: evidence from a high-resolution marine palynological record from

Sha, L., Jang, H., Knudsen, K.-L., 2012. Diatom evidence of climatic change in Holsteinborg Dyb,

361 Schmidt, S., Send, U., 2007. Origin and composition of seasonal Labrador Sea freshwater, J. Phys. 362 Oceanogr. $37,1145-1454$.

363 Schmidt S., Howa, H., Mouret, A., Lombard, F., Anschutz, P., Labeyrie, L., 2009. Particle fluxes and 364 recent sediment accumulation on the Aquitanian margin of Bay of Biscay. Cont. Shelf Res 29, $365 \quad 1044-1052$. 

Greenland. The Holocene 17,387-401. 2008. Variable North Atlantic climate seesaw patterns documented by a late Holocene marine record from Disko Bugt, West Greenland. Marine Micropaleontology 68, 66-83.

Sicre, M.-A., Hall, I. R., Mignot J., Khodri M., Ezat, U., Truong M.-X., Eiriksson, J. \& Knudsen, K.-L., 2011. Sea surface temperature variability in the subpolar Atlantic over the last two millennia,

Solignac, S., Seidenkrantz, M.-L., Jessen, C., Kuijpers, A., Gunvald, A.K., Oslen, J., 2011. LateHolocene sea-surface conditions offshore Newfoundland based on dinoflagellate cysts. The Holocene 2, 1-14.

Ternois, Y., Sicre, M.-A., Boireau, A., Marty, J.-C., and Miquel, J.-C., 1996. Production pattern of alkenones in the Mediterranean Sea. Geophys. Res. Lett. 23, 3171-3174.

Thompson, D.W.J., Wallace, J.M., 1998. The Arctic Oscillation signature in the wintertime geopotential height and temperature fields. Geophys. Res. Lett 25, 1297-1300.

Trouet, V., Esper, J., Graham, N. E., Baker, A., Scourse, J. D., Frank D.C., 2009. Persistent positive

384 Trouet, V., Scourse, J.D. \& Raible, C.C., 2012. North Atlantic storminess and Atlantic Meridional 385 Overturning Circulation during the last Millennium: reconciling contradictory proxy records of 386 NAO variability. Global and Planetary Change 84-85, 48-55. doi:

$387 \quad$ 10.1016/j.gloplacha.2011.10.003.

388 Weckström, K., Massé. G., Collins, L.G., Hanhijärvi, S., Bouloubassi, I., Sicre, M.-A., Seidenkrantz. 389 M.-S., Schmidt, S. Andersen, T.J., Andersen, M.L., Brian Hill, B. Kuijpers; A., 2013. Evaluation of 390 the sea ice proxy IP25 against observational and diatom proxy data in the SW Labrador Sea. 391 Quaternary Science Reviews 79, 53-62; http://dx.doi.org/10.1016/j.quascirev.2013.02.012. 
Figure 1. Map showing North Atlantic surface currents, the study area, regional wind directions and the coring sites. Red/blue arrows indicate warm/cold surface currents, respectively; the prevailing wind directions are marked with light blue arrows. Core sites are shown on the insert map with the detailed surface hydrology of the Newfoundland area (thick blue arrows $=$ Outer Labrador Current, thin blue arrows = Inner Labrador Current). Also shown in the insert are SST isolines (in ${ }^{\circ} \mathrm{C}$ ) based on the NODC (Levitus) World Ocean Atlas 1998 (1.0 degree latitude $\times 1.0$ degree longitude global grid; 10 meter depth; data provided by the NOAA/OAR/ESRL PSD, Boulder, Colorado, USA, from their Web site at http://www.esrl.noaa.gov/psd/). The isolines represent April-June means for the years 1900-1997, thus largely overlapping with the time period covered by our two box cores.

405

Figure 2. ${ }^{210} \mathrm{~Pb}$ profiles of box-cores AI07-04BC and AI07-11BC and age models established from the ${ }^{210} \mathrm{~Pb}$ data.

Figure 3. Age model of gravity cores AI07-03G and AI07-12G based on calibrated ${ }^{14} \mathrm{C}$ dates. The age models were established with the depositional model option in the OxCal 4.1 software using marine ${ }^{14} \mathrm{C}$ calibration curve Marine09 with an average $\Delta \mathrm{R}$ of $139 \pm 61$ years (Solignac et al.,

Figure 4. Comparison of alkenone-derived SST reconstructions from recent sediments and NAM index values.

(a) the NAM index was obtained from http://climatedataguide.ucar.edu/guidance/hurrell-wintertime-slp-based-northern-annular-modenam-index. The thick black line is the running 3-year mean, i.e. the temporal resolution of our 04BC) in light blue, and (c) off SE Newfoundland (Placentia Bay; box-core AI07-11BC) in dark blue.

Figure 5. Monthly mean temperature at the NE Newfoundland site (Bonavista Bay) in light blue, and at SE Newfoundland (Placentia Bay) in dark blue. Data have been obtained from the OES database (http://www2.mar.dfompo.gc.ca/science/ocean/coastal_temperature/coastal_temperature.html) in area 3Lb for the NE 
423 Newfoundland site and 3Ps for SE Newfoundland. Dotted lines represent annual means at both 424 sites.

425 Figure 6. SST proxy reconstructions for the last 2000 years from off Newfoundland and North 426 Iceland. Alkenone-derived SST reconstruction from (a) Off North Iceland obtained from the 427 Calypso core MD99-2275 (Sicre et al., 2011) (b) NE Newfoundland obtained from the gravity 428 core AI07-03G and box-core AI07-04BC for the upper part, and (c) SE Newfoundland obtained 429 from the gravity core AI07-12G and box-core AI07-11BC 04BC for the upper part. The grey 430 shading broadly indicates the Medieval Climate Anomaly (MCA). Black diamonds indicate AMS ${ }^{14} \mathrm{C}$ 431 - dated sediment layers used to build the age model. 